\title{
EFFECT OF ENVIRONMENTAL VARIABLES IN THE DISTRIBUTION OF TREE SPECIES IN THE IGUAÇU NATIONAL PARK ${ }^{1}$
}

\author{
Ronan Felipe Souza ${ }^{2 *}$, Sebastião Amaral Machado ${ }^{3}$, Franklin Galvão ${ }^{3}$ and Afonso Figueiredo Filho ${ }^{4}$
}

\footnotetext{
${ }^{1}$ Received on 20.01.2017 accepted for publication on 24.11.2017.

${ }^{2}$ Universidade Estadual do Oeste do Paraná, Campus Universitário de Cascavel, Cascavel, PR - Brasil. E-mail: <ronanflorestal@gmail.com>. ${ }^{3}$ Universidade Federal do Paraná, Departamento de Ciências Florestais, Curitiba, PR - Brasil. E-mail: <samachado@ufpr.br $>$ and <fgalvao@ufpr.br>.

${ }^{4}$ Universidade Estadual do Oeste do Paraná, Departamento de Engenharia Florestal, Irati, PR - Brasil. E-mail:<afigfilho@gmail.com>.

*Corresponding author.
}

\begin{abstract}
The knowledge of the environmental variable seffect on the distribution of tree species is of great importance, since it contributes to a greater efficiency on the management of forests and on the conservation of degraded areas. In order to identify these effects on native species from the western region of Paraná, 21 plots of 2,000 $\mathrm{m}^{2}$ were installed in the Iguaçu National Park. The plots were distributed along the altitude gradient, between 150 and $750 \mathrm{~m}$, and in different positions of the drainage ramps, from the river banks to the plateau regions. After the data processing carried out by Canonical Correspondence Analysis, it was identified species that are distributed in the vegetation according to the variations of altitude, humidity, fertility, saturation by aluminum and soil clay content. Some species presented tolerance to the environmental variations, a typical characteristic of species of wide geographic occurrence.
\end{abstract}

Keywords: Environmental characteristics; Ecology of species; Multivariate analysis.

\section{EFEITO DE VARIÁVEIS AMBIENTAIS NA DISTRIBUIÇÃO DE ESPÉCIES ARBÓREAS NO PARQUE NACIONAL DO IGUAÇU}

\begin{abstract}
RESUMO - O conhecimento do efeito das variáveis ambientais na distribuição das espécies arbóreas é de grande importância, pois contribui para uma maior eficiência no manejo de florestas e na conservação de áreas degradadas. Com o objetivo de identificar estes efeitos para espécies nativas da região Oeste do Paraná, foram instaladas 21 parcelas de $2.000 \mathrm{~m}^{2}$ no Parque Nacional do Iguaçu. As parcelas foram distribuídas ao longo do gradiente de altitude, entre 150 e $750 \mathrm{~m}$, e em diferentes posições nas rampas de drenagem, desde as margens dos rios até as regiões de platô. Após o processamento dos dados, realizado por meio da Análise de Correspondência Canônica, foram identificadas espécies que se distribuem na vegetação de acordo com as variações de altitude, umidade, fertilidade, saturação por alumínio e teor de argila do solo. Algumas espécies apresentaram tolerância às variações ambientais, característica típica de espécies de ampla ocorrência geográfica.
\end{abstract}

Palavras-Chave: Características ambientais; Ecologia de espécies; Análise multivariada. 


\section{INTRODUCTION}

Preserved remnants from forests of the Atlantic Forest in Paraná are now reduced to Conservation Units (CU), a result of the intense deforestation that occurred in the past decades, driven by disordered agricultural expansion (Sonda and Trauczynski, 2010). In the rural properties of this region, where Permanent Preservation Areas (PPAs) and Legal Reserves (LR) have to be occupied by native forest species, degraded forests and ineffective forestry projects are observed, as a result of the lack of information on the ecology of existing species.

One of the aspects of great importance for the understanding of the forest species ecology is the identification of the effect of the environmental, climatic and pedological characteristics, on their natural distribution. Information that contributes to a better orientation of planting and management, reducing mortality and favoring its development are required.

In order to identify these relationships for different species, the use of multivariate analyzes in different regions of Brazil has been satisfactorily performed (Oliveira-Filho and Fontes, 2000; Budke et al., 2007; Ferreira-Júnior et al., 2007; Marques et al., 2011; Sanchez et al., 2013). Ter Braak (1986, 1987) also reported that, among ordination techniques, Canonical Correlation Analysis (CCA) is preferentially indicated when the objective is to study more deeply the relations between environmental variables and species density.

In this context, in order to identify the environmental variables effect on the natural distribution of the native forest species of the West of the state of Paraná and, in this way to contribute to its conservation and management, this study was developed in Iguaçu National Park (INP). The CU was chosen because it has an extensive area of preserved and fully protected forest.

\section{MATERIALAND METHODS}

\subsection{Study area}

The Iguaçu National Park (INP) is located in the Atlantic Forest biome, in the western region of the state of Paraná, Brazil, with a total area of 185,262.50 hectares (ha) (Ferreira, 1999). The predominant climate is of type Cfa which extends to altitudes close to 750 $\mathrm{m}$; from this altitude it occurs the climatic type $\mathrm{Cfb}$ (Alvares et al., 2013).
The relief is subordinate to the basin of the Iguaçu river and presents an altitude gradient that varies from 100 to approximately 750 meters $(\mathrm{m})$ above sea level (a.s.1.), as it moves away from the channel of this river (Ferreira, 1999). Salamuni et al. (2002) pointed out that this National Park presents two geomorphological compartments: (I) the Central and North region formed by a more rugged relief, locally steep relief, characterizing more elongated and carved interfluves with undulated hills to strongly undulated; (II) the southern region, formed by gently rolling to rolling hills, with predominance of tabular forms that, strictly speaking, are a constant in the Paraná basaltic spills.

Souza et al. (2017) have identified in the Park Eutrophic MELANIC Tb GLEISSOLO, Eutrophic REGOLITIC NEOSOLS, Dystrophic RED LATOSOL, Eutrophic RED LATOSOL and Eutrophic RED NITOSOL; the last two with the greatest recurrence. Bhering (2007) reported, in addition, the occurrence of ORTHIC RENDZIC CHERNOSOL, HAPLIC GLEISSOL and Eutrophic LITOLIC NEOSOL.

The predominant vegetation is of the Semideciduous Seasonal Forest (SSF) type, in the northern portion of the Park is observed an Ecotone of this vegetation with the Montana Mixed Ombrophylous Forest (MOF), at altitudes around $750 \mathrm{~m}$. The SSF that occurs is divided into Montana $(750 \mathrm{~m})$ and Submontana $(650 \mathrm{~m})$ formations, the latter subdivided into two sub-formations: (I) Humid, in the valleys that accompany the water courses, where there is pedological variability and greater humidity, without occurrence of hydromorphism or alluvial deposition in the soil due to the bed of the watercourses being controlled by geological faults and; (II) Typical on plateaus with deep soils and lower humidity (Souza et al., 2017).

\subsection{Data and Analysis}

For vegetation sampling, seven groups of three plots were distributed along the altitude gradient of the Park and internalized in the vegetation in the westeast direction (Figure 1). In each group, the plots were positioned perpendicular to the drainage ramps and with variable distances between them, distributed from the base to the plateau regions, close to the water dividers. In total, 21 plots with a sample area of $2,000 \mathrm{~m}^{2}(20$ $\mathrm{x} 100 \mathrm{~m}$ ) were installed, totaling 4.20 hectares (ha) of sampled area.

Revista Árvore. 2017;41(6):e410609 


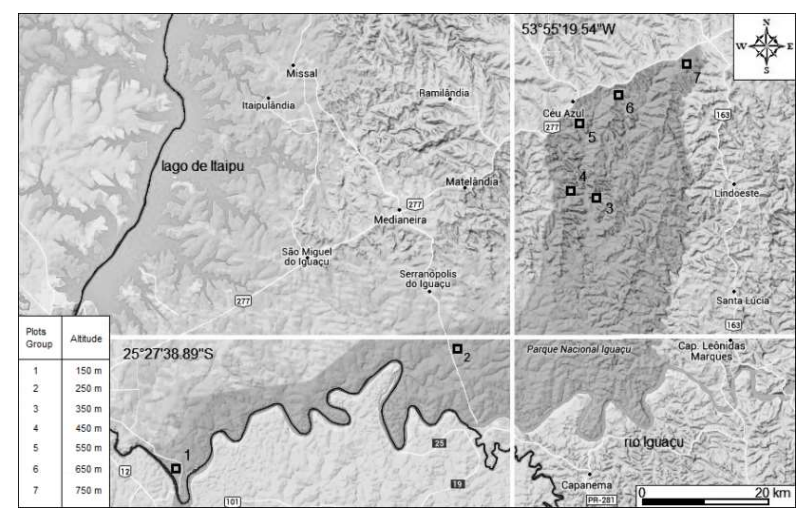

Figure 1 - Location of the plots group installed in the Iguaçu National Park.

Figura 1 - Localização dos grupos de parcelas instaladas no Parque Nacional do Iguaçu.

This design was used in order to ensure that sampling was performed at the different levels of environmental gradients in the Park. The design was adapted from the studies of Oliveira-Filho et al. (1994); Ferreira-Junior et al. (2007); Higuchi et al. (2008) and Giehl and Jarenkow (2008). The plot surface was defined based on considerations made by Augustynczik et al. (2013).

The circumferences were measured at $1.30 \mathrm{~m}$ from the soil, with metric tape, of all live trees with a circumference of 15.70 centimeters or more $(\mathrm{DBH} \geq$ $5.00 \mathrm{~cm}$ ). The species were identified in the Botanical Museum of Curitiba and, when necessary, the botanical material collected in the field was sent to specialists. The species nomenclature follows the Missouri Botanical Garden (tropicos.org) and the classification follows Angiosperm Phylogeny Group (2009).

It was used the CCA (Ter Braak, 1986, 1987) for the analysis of the effect of environmental variables on species management. Data processing was performed by PC-ORD for Windows version 6.0 software (McCune and Mefford, 2011). In the CCA the main matrix was formed by the 70 species that presented density greater than or equal to 10 individuals (columns), distributed in the 21 plots (lines); however, the values were transformed to $\log _{10}(\mathrm{x}+1)$ with the objective to reduce variance (Palmer, 1993). The secondary matrix was formed by the 19 environmental variables (columns) recorded in the 21 plots (lines); to reduce the variance the values were transformed to $\log _{10}(\mathrm{x}+1)$ and normalized to a standard normal distribution.
The secondary matrix presented the values for altitude, slope, soil drainage, humidity, clay, silt, sand, $\mathrm{pH}, \mathrm{C}, \mathrm{P}, \mathrm{K}^{+}, \mathrm{Ca}^{+2}, \mathrm{Mg}^{+2}, \mathrm{Al}^{+3}, \mathrm{H}^{+}+\mathrm{Al}^{+3}$, as well as, Sum of Bases (SB), Cation Exchange Capacity (CEC), Saturation by bases (V\%) and by Aluminum Saturation $(\mathrm{Al} \%)$. The altitude in each plot was attributed according to the altitude plateau in relation to sea level, varying from 150 to $750 \mathrm{~m}$ above sea level. For the determination of the physical and chemical characteristics of the soil, a homogenized composite sample of $500 \mathrm{~g}$ of superficial soil (zero to $20 \mathrm{~cm}$ ) collected at five points along the central line of each plot was analyzed in the laboratory.

Slope and soil drainage were determined according to Empresa Brasileira de Pesquisa Agropecuária (2006), referenced in numerical values from one to five. The following classes were adopted for slope: (1) flat (0$3 \%)$; (2) soft-undulated (3-8\%); (3) undulated (8-20\%); (4) strong-undulated (20-45\%) and; (5) mountainous $(45-75 \%)$. Soil drainage classes were: (1) very poorly drained; (2) moderately drained; (3) well drained; (4) and; (5) strongly drained.

The humidity of the environment was categorized into three levels. Determined arbitrarily, taking into account the field observations in each plot, the position in the drainage ramp and the distance from the bed of the existing rivers; the geographic orientation of the drainage ramps and their respective time of direct sun exposure were also considered. The moisture classes were: (1) low; (2) intermediary and; (3) high.

The CCA was carried out in two stages. Initially containing all the environmental variables and, in the sequence, only those that presented canonical correlation greater than 0.50 for at least one of the ordering axes, considered significant in the distribution of the species (Ter Braak, 1986, 1987; Palmer, 1993). Redundant variables with high correlation were also excluded from the final matrix of environmental data.

\section{RESULTS}

\subsection{Observed Environmental Characteristics}

It is possible to observe high variability of environmental characteristics in the plots allocated along the altitude gradient of the PNI (Table 1). However, it should be noted, that the plots at altitude of $150 \mathrm{~m} \mathrm{did}$ not show variability for any of the factors analyzed; the slope did not vary in the plots in 650 and $750 \mathrm{~m}$ and the soil class did not change in the altitude of $750 \mathrm{~m}$.

Revista Árvore. 2017;41(6):e410609 


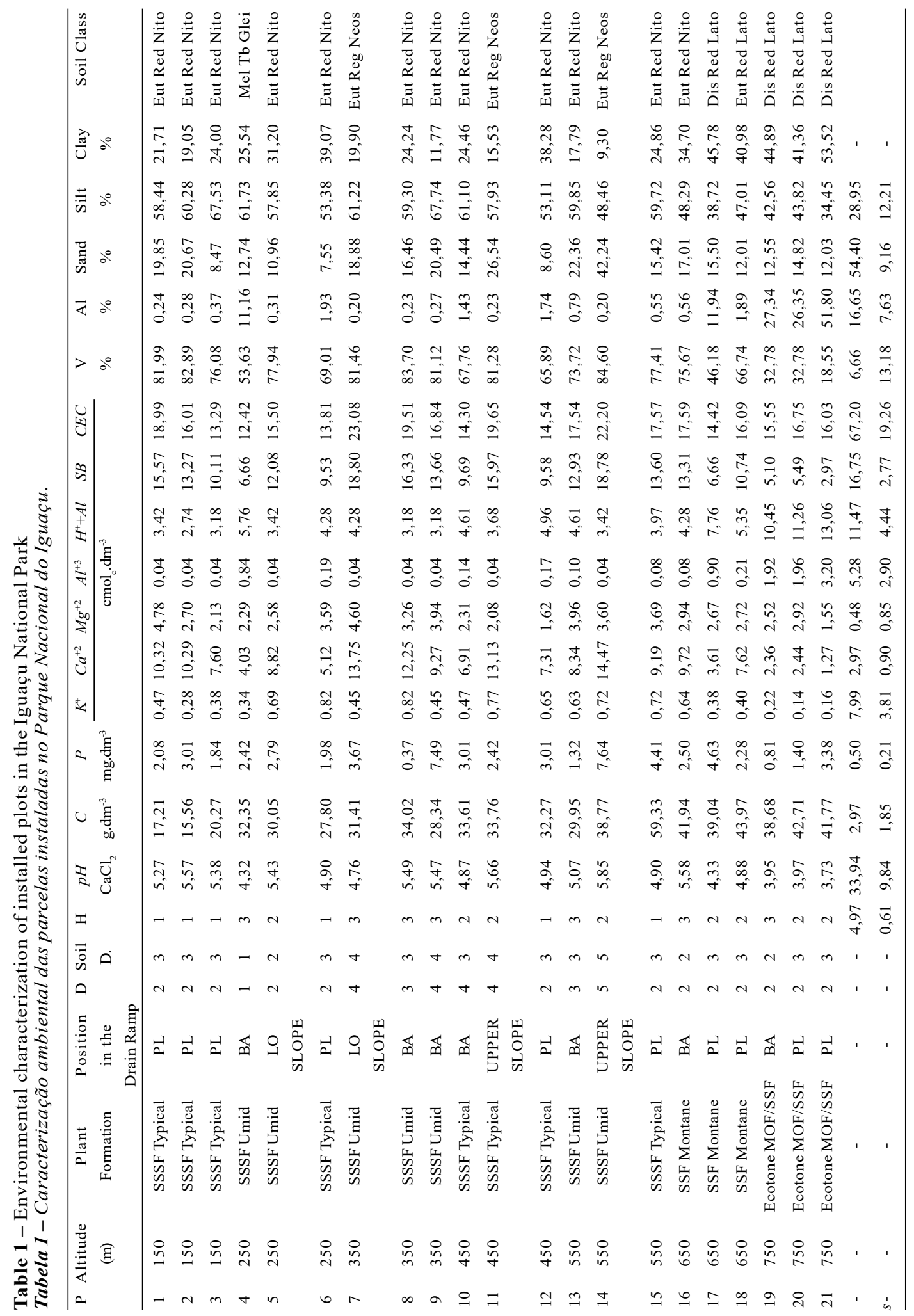

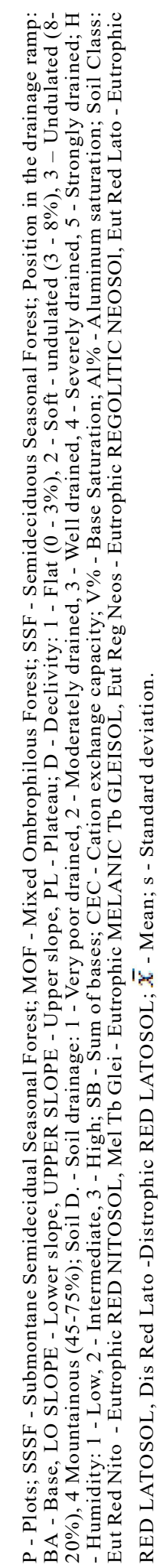




\subsection{Vegetation Ordering}

The five variables that formed the final CCA matrix were: altitude (m), $\mathrm{V} \%, \mathrm{Al} \%$, clay content $(\%)$ and humidity. The total variance that could be explained in the species density matrix was 1.22 and, from this total, $29.20 \%$ was explained by the first two ordering axes, 17.60 and $11.60 \%$, respectively. The eigen values observed for both axes were 0.21 and 0.14 .

Correlations of 0.95 and 0.84 between the ordering axes and the environmental variables were accepted, since the Monte Carlo test presented high significance for the first axis $(p$-value $=0.001)$. This result indicated that there is no linear relationship between the data matrices.
The canonical correlation of the environmental variables with the ordering axes followed the same trend of the Pearson correlation ( $r$ ) observed among the variables, with exception of humidity, which was better correlated with the second axis (Table 2). Altitude, aluminum saturation and clay content showed a positive correlation with the first axis, as opposed to base saturation, which was negatively correlated with this axis.

Figure 2 shows the ordering diagram for the 21 plots and 70 species analyzed, which were codified to facilitate visualization; the code for each species is shown between parentheses throughout the text, after their respective citation. There are two gradients in the distribution of plots and species: one strongly associated with altitude variation, soil fertility, clay

Table 2 - Intraset correlation for the two first CCA ordination axes and Pearson correlation (r) for standardized environmental variables.

Tabela 2 - Correlação "intraset" para os dois primeiros eixos de ordenação da CCA e correlação de Pearson (r) para as variáveis ambientais padronizadas.

\begin{tabular}{|c|c|c|c|c|c|c|}
\hline \multirow[t]{2}{*}{ Variable } & \multirow[t]{2}{*}{ Axis 1} & \multirow[t]{2}{*}{ Axis 2} & \multicolumn{4}{|c|}{$r$} \\
\hline & & & Altitude & $V \%$ & $A l \%$ & Clay $\%$ \\
\hline Altitude (m) & 0.68 & -0.26 & - & - & - & - \\
\hline$V \%$ & -0.98 & -0.09 & -0.54 & - & - & - \\
\hline$A l \%$ & 0.91 & 0.05 & 0.51 & -0.96 & - & - \\
\hline Clay\% & 0.68 & -0.46 & 0.39 & -0.70 & 0.70 & - \\
\hline Humidity & 0.13 & 0.56 & 0.35 & -0.15 & 0.18 & -0.06 \\
\hline
\end{tabular}

$V \%$ - Saturation by bases; $A l \%$ - Saturation by aluminum; Clay \% - Soil clay content.
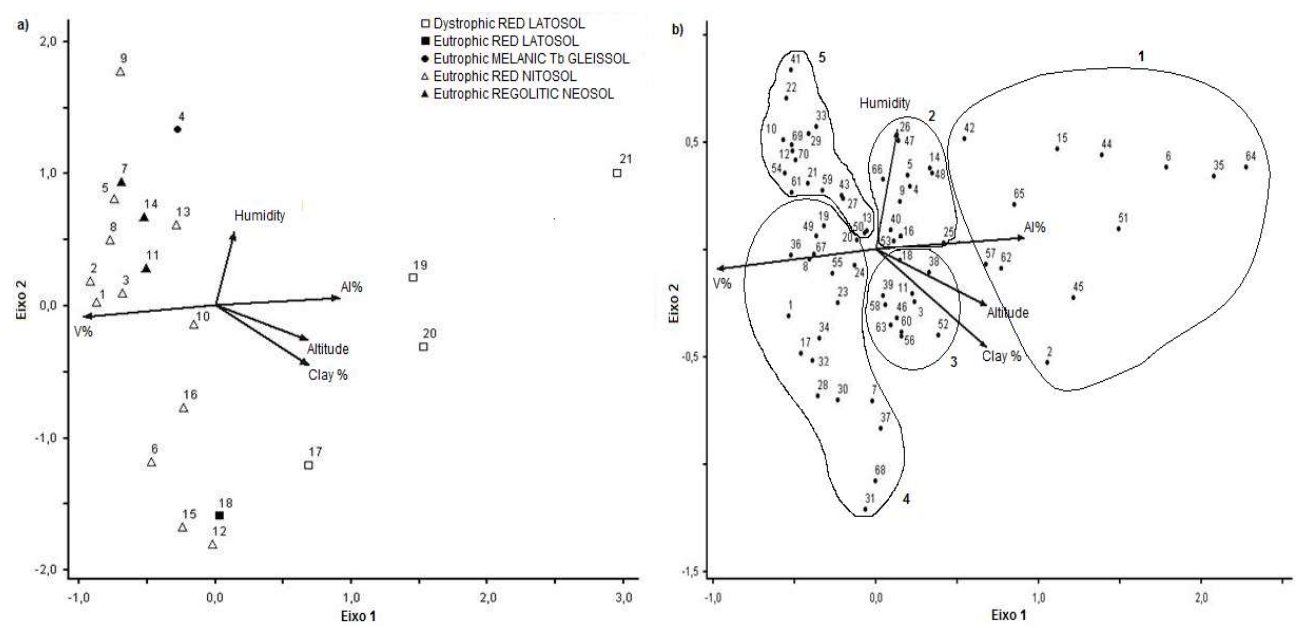

Figure 2 - a) Ordering diagram for the distribution of the 21 plots. b) Ordering diagram for the distribution of the 70 species and groups of species created according to similar environmental characteristics. V\% - Saturation by base; Al\% - Aluminum saturation; Clay \% - Soil clay content.

Figura 2 - a) Diagrama de ordenação para a distribuição das 21 parcelas. b) Diagrama de ordenação para a distribuição das 70 espécies e grupos de espécies formados de acordo com características ambientais semelhantes. V\% - saturação por bases; Al\% - saturação por alumínio; Clay\% - percentual de argila. 
content and saturation by aluminum, and another associated with humidity.

Plot 21 stood out at the right end of the diagram, while plots 19 and 20, due to lower $\mathrm{Al} \%$ and clay content, were positioned a little more to the center. The reduction of aluminum saturation and of an altitude plateau, as well as the increase in soil fertility of plots 16 and 18 , were responsible for their position in the lower left portion of the diagram. Plot 17 appeared more to the right, result of the dystrophic soil, higher A1\% and clay content.

The highest concentration of plots on the left side of the diagram was a result of the predominance of high fertility soils with reduced $\mathrm{Al} \%$ and clay content in the lower PNI regions. However, the variation of humidity between the environments of this region associated to the proximity to the river beds contributed strongly to the dispersion of the plots in the diagram.

In the upper portion were placed plots $4,5,7,8$, 9 and 13, which presented high humidity, as well as plot 14 that presented intermediate humidity. A little further down, positioned next to the $\mathrm{V} \%$ vector, plots 1,2 and 3 were positioned; this result is justified by low humidity and high fertility. Plots 10 and 11 , further to the center, were thus positioned because of the intermediate altitude and humidity. In the lower left portion of the diagram were placed plots 6, 12 and 15, reflecting mainly the low humidity.

The species were distributed in a dispersed manner and according to the respective densities in the plots. The further away from the center and close to a given vector, the greater was its association with it, as well as the other environmental vectors that make up the canonical axis. The closer to the center of the diagram, the greater the tolerance (plasticity) of the species in relation to the environmental variables represented by the set of vectors that make up the diagram.

In the right portion of the diagram a group formed by species with a score greater than 0.50 for the first ordering axis was observed, which presented higher density in plots 19,20 and 21. This group was formed by Alchornea glandulosa (2), Araucaria angustifolia (6), Casearia obliqua (15), Ilex paraguariensis (35), Luehea divaricata (42), Matayba elaeagnoides (44), Mollinedia clavigera (45), Ocotea indecora (51), Prunus myrtifolia (62), Styrax acuminatus (64) and Styrax leprosus (65).

Revista Árvore. 2017;41(6):e410609
Some species with a positive score for the first ordering axis, between zero and 0.50 , were positioned in the upper portion of the diagram, close to the Moisture vector; this result is associated with the recurrence of these species, both in the higher altitude plots and in the plots with higher fertility and high humidity soils at lower altitudes. This is the case of Allophylus edulis (4), Annona emarginata (5), Banara tomentosa (9), Casearia decandra (14), Casearia sylvestris (16), Cupania vernalis (25), Dalbergia frutescens (26), Lonchocarpus campestris), Myrsine umbellata (47), Nectandra lanceolata (48), Parapiptadenia rigida (53) and Syagrus romanzoffiana (66).

A third group, which is also positively associated to the first ordering axis, between zero and 0.50 , was formed by species that were positioned at the bottom of the diagram. This group was composed by species that were positively associated with the highest altitudes, but that also occurred in environments with fertile soils and low humidity, located at lower altitudes. The species of this group were Alchornea triplinervia (3), Cabralea canjerana (11), Cedrella fissilis (18), Jacaranda micrantha (38), Jacaratia spinosa (39), Myrocarpus frondosus (46), Ocotea silvestris (52), Prockia crucis(56), Psychotria carthagenensis (58), Sebastiania commersoniana (60) and Sorocea bonplandii (63).

In the lower left portion of the diagram were placed species that presented higher density in the plots between 150 and $650 \mathrm{~m}$ and that presented predominantly high fertility and low humidity. Belong to this group the following species: Acacia bimucronata (1), Aspidosperma polyneuron (7), Balfourodendron riedelianum (8), Cecropia pachystachya (17),Chrysophyllum gonocarpum (19), Chrysophyllum marginatum (20), Cordia ecalyculata (23), Cordia trichotoma (24), Eugenia burkartiana (28), Euterpe edulis (30), Ficus luschnathiana (31), Guarea kunthiana (32), Holocalyx balansae (34), Inga marginata (36), Ixora venulosa (37), Nectandra megapotamica (49), Plinia rivularis (55), Trichilia catigua (67) and Trichilia claussenii (68). In this group, species that positioned more to the left and above were less tolerant to altitude increase and more tolerant to increase of humidity, respectively.

In the upper left portion of the diagram are positional the species of the fifth group: Bastardiopsis densiflora (10), Calliandra foliolosa (12), Campomanesia xanthocarpa (13), Citrus sinensis (21), Cordia americana 
(22), Diatenopteryx sorbifolia (27), Eugenia subterminalis (29), Hennecartia omphalandra (33), Lonchocarpus nitidus (41), Machaeriumstipitatum (43), Ocotea diospyrifolia (50), Pilocarpus pennatifolius (54), Sebastiania brasiliensis (59), Seguieria guaranitica (61), Trichilia elegans (69) and Ureara baccifera (70). This result is due to the higher density in the plots installed at lower altitudes, which presented as outstanding characteristics the high fertility of the soil and the high humidity.

\section{DISCUSSION}

Humidity was the only variable well correlated with the second canonical axis, as a result of the low correlation with all other variables. This result can be explained by the location of the plots in humid environments along the altitude gradient analyzed, from the montana environments, with low fertility soils and the transition climate between $\mathrm{Cfa}$ and $\mathrm{Cfb}$, to submontane environments, with high fertility soils, Cfa climate and located on the banks of the waterways, at the base of the drainage ramps.

The CCA explained $29.20 \%$ of the variance observed in the density matrix, indicating that the species distribution presented a lot of unexplained variance, a common result in vegetation studies (TER BRAAK, 1987). The canonical axes, however, were not compromised, since no significant differences were observed between the data matrices by the Monte Carlo permutation test.

Ferreira-Júnior et al. (2007) explained more than $50 \%$ of the variance with a matrix of 28 species and five environmental variables. These authors obtained eigen values of 0.37 and 0.17 , respectively, for the first two ordering axes, which explained 38.70 and $17.70 \%$. Cordeiro (2010) also found higher values for the variance explained by the ordering axes when analyzing a matrix of 25 species and five environmental variables, reaching $79.80 \%$.

Botrel et al. (2002) found results close to the present study when analyzing a matrix of 48 species and four environmental variables, totaling $27.20 \%$ of the total variance explained by the two first ordering axes. It is noteworthy, when comparing these results, a negative correlation between the numbers of species analyzed and the respective variance explained.
In the right portion of the diagram, associated with the highest altitude and low fertility soils with high aluminum content, the characteristics of the Ecotone MOF/SSF environment in the PNI (Souza et al., 2017), were positioned the preferential species of ombrophylous forests $A$. angustifolia and I. paraguariensis (Saueressig, 2012). Reissmann et al. (1999) identified I. paraguariensis occurring naturally also in acidic soils with high aluminum content. Cordeiro (2010), on the other hand, identified $A$. angustifolia on deep soils of the type Bruno LATOSSOL and Humic CAMBISSOL, the latter with high levels of Al\%. Other researchers who also identified $A$. angustifolia associated to soils with higher acidity and aluminum contents were Silva et al. (2012).

In the lower part of the ordering diagram, recurrent species were observed in plots with high fertility and low humidity soils located in plateau regions at altitudes of 150 to $650 \mathrm{~m}$. Holz et al. (2009) also identified $G$. kunthiana and E. edulis in regions with similar characteristics, emphasizing that they are recurrent species mainly in forest environments in an advanced stage of conservation. E. edulis, A. triplinervia and T. claussenii also appear in Jarenkow and Waechter (2001) studies in an environment similar to the PNI. Del Quiqui et al. (2007) also found in a plateau of SSF Submontana, in the north of Paraná, H. balansae and A. polyneuron. Costa et al. (2006), in turn, cited $A$. polyneuron and $B$. riedelianum under the same environmental conditions.

M. frondosus also appears in the upper portion of the diagram, slightly to the right due to the higher occurrence in the intermediate altitude regions (450 to $650 \mathrm{~m}$ ). Scipioni et al. (2011) observed this species in a seasonal forest of soft-undulated relief and well drained soils, with altitudes around $550 \mathrm{~m}$. Saueressig (2012), also pointed out that the species, typical of seasonal forests, occasionally occurs in ombrophylous forests.

Oliveira-Filho et al. (1994) and Botrel et al. (2002) mentioned that caution must be exercised in the interpretation of certain correlations between species and environmental variables in the CCA. An example is $S$. commersoniana, which was positioned at the bottom center of the diagram, known as preferential species of humid environments (Botrel et al., 2002; Barddal et al., 2004; Scipioni et al., 2013). The positioning of 
this species in this region of the diagram was associated to the reduction of its occurrence in the plots in lower altitude environments, with high humidity and high fertility soils.

S. brasiliensis, a species of the same family of S. commersoniana, located in the upper portion of the diagram, is also described as preferential in humid environments by Botrel et al. (2002) and Barddal et al. (2004). Ferreira (1999) has also recorded the recurrence of this species in this type of environment of the INP, as well as the absence of $S$. commersoniana at lower altitudes, which corroborates with the results observed in this research.

Also in the upper region of the diagram, $C$. americana, L. nitidus and M. stipitatum were associated with high humidity in SSF Submontana regions, which were also observed by Scipioni et al. (2013) in an Alluvial Submontana FED. Costa et al. (2006) found high densities of $B$. densiflora in a Fluvic Neossol, corroborating the distribution of this species in the Park.

Also in the upper portion of the diagram, A. edulis, C. decandra, C. obliqua, D. frutescens, L. divaricata, M. elaeagnoides, M. umbellata, S. leprosus and $S$. romanzoffiana were positioned between the vectors Moisture and Al \%. These species are commonly observed in alluvial environments and drainage headwaters, both in seasonal forests and in ombrophilous forests (Boutrel et al., 2002; Araujo et al., 2004; Barddal et al., 2004; Curcio et al., 2007; Giehl and Jarenkow, 2008; Silva et al., 2012; Scipioni et al., 2013).

For the species that presented low canonical value for both ordering axes, near the center of the diagram, greater plasticity was attributed. This was the case of C. canjerana, C. xanthocarpa, C. sylvestris, C. fissilis, C. marginatum, C. trichotoma, L. campestris, $O$. diospyrifolia and $P$. rigida. Scipioni et al. (2013) identified species occurring in environments with different water conditions such as C. marginatum, C. trichotoma, C. xanthocarpa and C. sylvestris. Ríos et al. (2010) also pointed out that $C$. canjerana and $C$. fissilis show wide dispersion, occurring from the Amazon basin to the northeast of Argentina.

\section{CONCLUSIONS}

The natural distribution of many of the native species evaluated in this study was affected by environmental factors, such as altitude, humidity, fertility, aluminum saturation and soil clay content. The results obtained allow us to suggest the use of these species in recovery, conservation and management projects in degraded forest remnants of the Atlantic Forest.

\section{ACKNOWLEDGMENTS}

To the Chico Mendes Institute for Biodiversity Conservation (ICMBio) for the authorization and availability of the physical structure to carry out this study; the Coordination for the Improvement of Higher Education Personnel (CAPES) for financial support in the form of a scholarship; and to the National Council for Scientific and Technological Development (CNPQ) for the financial assistance to carry out the fieldwork.

\section{REFERENCES}

Alvares AA, Stape JL, Sentelhas PC, Gonçalves JLM, Sparovek G. Köppen's climate classification map for Brazil. Meteorologische Zeitschrift. 2013;6(22):711-28. http://dx.doi.org/10.1127/09412948/2013/0507.

Angiosperm Phylogeny Group. An update of the Angiosperm Phylogeny Group classification for the orders and families of flowering plants: APG III. Bot J Linn Soc. 2009;161(2):105-21. http:// dx.doi.org/10.1111/j.1095-8339.2009.00996.x.

Araujo MM, Longhi SJ, Brena DA, Barros PLC, Franco S. Análise de agrupamento da vegetação de um fragmento de floresta estacional decidual aluvial, Cachoeira do Sul, RS, Brasil. Cienc Florest. 2004;14(1):133-47. http://dx.doi.org/ $10.5902 / 198050981789$.

Augustynczik ALD, Machado SA, FigueiredoFilho A, Pellico S No. Avaliação do tamanho de parcelas e de intensidade de amostragem em inventários florestais. Sci For. 2013;41(99):361-8.

Barddal ML, Roderjan CV, Galvão F, Curcio GR. Fitossociologia do Sub-bosque de uma Floresta Ombrófila Mista Aluvial, no Município de Araucária, PR. Cienc Florest. 2004;14(1):35-45. http://dx.doi.org/10.5902/198050981779.

Bhering SB. Mapa de solos do Estado do Paraná: escala 1:250.000. Rio de Janeiro: Embrapa Solos; 2007. (Documentos; no. 96). 
Botrel RT, Oliveira AT Fo, Rodrigues LA, Curi N. Influência do solo e topografia sobre as variações da composição florística e estrutura da comunidade arbórea-arbustiva de uma floresta estacional semidecidual em Ingaí, MG. Rev Bras Bot Braz J Bot. 2002;25(2):195-213. http:// dx.doi.org/10.1590/S0100-84042002000200008.

Budke JC, Jarenkow JA, Oliveira-Filho AT. Relationships between tree component structure, topography and soils of a Riverside Forest, Rio Botucaraí, Southern Brazil. Plant Ecol. 2007;189(2):187-200. http://dx.doi.org/10.1007/ s11258-006-9174-8.

Cordeiro J. Compartimentação PedológicoAmbiental e sua Influência sobre a Florística e Estrutura de um Remanescente de Floresta Ombrófila Mista na Região Centro-Sul do Paraná [tese]. Curitiba: Universidade Federal do Paraná, Setor de Ciências Agrárias, Programa de Pósgraduação em Engenharia Florestal; 2010.

Costa LV Fo, Nanni MR, Campos JB. Floristic and phytosociological description of a riparian forest and the relationship with the edaphic enviroment in Caiuá Ecological Station, Paraná, Brazil. Braz Arch Biol Technol. 2006;49(5):785-98. http://dx.doi.org/10.1590/S151689132006000600013.

Curcio GR, Galvão F, Bonnet A, Barddal ML, Dedecek RA. A floresta fluvial em dois Compartimentos do Rio Iguaçu, Paraná, Brasil. Floresta. 2007;37(2):125-47. http://dx.doi.org/ $10.5380 /$ rf.v37i2.8645.

Del Quiqui EM, Martins SS, Silva IC, Borghi WA, Silva OH, Sakuragui CM, et al. Estudo Fitossociológico de um Trecho da Floresta Estacional Semidecidual em Diamante do Norte, Estado do Paraná, Brasil. Acta Sci Agron. 2007;29(2):283-90.

Empresa Brasileira de Pesquisa Agropecuária. Sistema Brasileiro de Classificação de Solos. 2. ed. Brasília: Embrapa Produção de Informação; Rio de Janeiro: Embrapa Solos, 2006. 306 p.

Ferreira LM. Caracterização Ambiental do Parque Nacional do Iguaçu e sua Zona de Transição: Encarte 5, com Vistas à Revisão do Plano de Manejo. Brasília: IBAMA; 1999.
Ferreira-Júnior WG, Silva AF, Schaefer CEGR, Meira JAA No. Influence of Soils and Topographic Gradients on Tree Species Distribution in a Brazilian Atlantic Tropical Semideciduous Forest. Edinb J Bot. 2007;64(2):137-57. http://dx.doi.org/10.1017/ S0960428607000832.

Giehl ELH, Jarenkow JA. Gradiente Floresta Ribeirinha, Rio Uruguai, Sul do Brasil. Acta Bot Bras. 2008;22(3):741-53. http://dx.doi.org/10.1590/ S0102-33062008000300012.

Higuchi P, Oliveira-Filho AT, Silva AC, Machado ELM, Santos RM, Pifano DS. Dinâmica da comunidade arbórea em um fragmento de floresta estacional semidecidual montana em Lavras, Minas Gerais, em diferentes classes de solos. Árvore. 2008;32(3):417-26.

Holz S, Placci GP, Quintana RD. Effects of History of use on secondary Forest regeneration in the Upper Parana Atlantic Forest (Misiones, Argentina). For Ecol Manage. 2009;258(7):1629-42. http://dx.doi.org/10.1016/j.foreco.2009.07.023.

Jarenkow JA, Waechter JL. Composição, Estrutura e Relações Florísticas do componente Arbóreo de uma Floresta Estacional no Rio Grande do Sul, Brasil. Rev Bras Bot Braz J Bot. 2001;24(3):263-72. http://dx.doi.org/10.1590/S0100-84042001000300004.

Marques MCM, Swaine MD, Liebsch D. Diversity, Distribution and Floristic Differentiation of the Coastal Lowland Vegetation: Implications for the Conservation of the Brazilian Atlantic Forest. Biodivers Conserv. 2011;20(1):153-68. http:// dx.doi.org/10.1007/s10531-010-9952-4.

Mccune B, Mefford MJ. PC-ORD: multivariate analysis of ecological data. Version 6.0. Oregon: MjM Software; 2011.

Oliveira-Filho AT, Vilela EA, Gavilaness ML, Carvalho DA. Comparison of the woody flora and soils of six areas of montane semideciduous forest in southern Minas Gerais, Brazil. Edinb J Bot. 1994;51(03):355-89. http://dx.doi.org/10.1017/ S0960428600001839.

Oliveira-Filho AT, Fontes MA. Patterns of Floristic Differentiation among Atlantic Forest in Southeastern Brazil and the Influence of Climate.

Revista Árvore. 2017;41(6):e410609 
Biotropica. 2000;32(4b):793-810. http://dx.doi.org/ 10.1111/j.1744-7429.2000.tb00619.x.

Palmer MW. Putting things in even better order: the advantages of canonical correspondence analysis. Ecology. 1993;74(8):2215-30. http:// dx.doi.org/10.2307/1939575.

Reissmann CB, Radomski MI, Quadros RMB. Chemical Composition of Ilexparaguariensis $\mathrm{St}$. Hil. Under Different Management Conditions in Seven Localities of Paraná State. Braz Arch Biol Technol. 1999;42(2):187-94. http://dx.doi.org/ 10.1590/S1516-89131999000200009.

Ríos RC, Galvão F, Curcio GR. Estructura de las Principales Especies Arbóreas en el Parque Cruce Caballero y su Similitud Floristica con Areas de Argentina y de Brasil. Cienc Florest. 2010;20(2):193-206. http://dx.doi.org/10.5902/ 198050981843.

Salamuni R, Salamuni E, Rocha LA, Rocha AL. Sítios geológicos e paleontológicos do Brasil. Brasília: DNPM; 2002. Cataratas de fama mundial; 554 p.

Sanchez M, Pedroni F, Eisenlohr PV, Oliveira-Filho AT. Changes in Tree Community Composition and Structure of Atlantic Rain Forest on a Slope of the Serra do Mar Range, Southeastern Brazil, from Near Sea Level to $1000 \mathrm{~m}$ of Altitude. Flora. 2013;208(3):184-96. http://dx.doi.org/10.1016/ j.flora.2013.03.002.

Saueressig D. Levantamento dendrológico na floresta ombrófila mista e implementação de um sistema de identificação "online" [dissertação]. Curitiba: Universidade Federal do Paraná, Setor de Ciências Agrárias, Programa de Pós-graduação em Engenharia Florestal; 2012.
Scipioni MC, Finger CAG, Cantarelli EB, Denardi L, Meyer EA. Fitossociologia em fragmento florestal no noroeste do Estado do Rio Grande do Sul. Cienc Florest. 2011;21(3):407-17. http:// dx.doi.org/10.5902/198050983799.

Scipioni MC, Galvão F, Longhi SJ. composição florística e estratégias de dispersão e regeneração de grupos florísticos em florestas estacionais deciduais no Rio Grande do Sul. Floresta. 2013;43(2):241-54. http://dx.doi.org/ 10.5380/rf.v43i2.27098.

Silva AC, Higuchi P, Aguiar MD, Negrini M, Fert J No, Hess AF. Relações florísticas e fitossociologia de uma floresta ombrófila mista montana secundária em Lages, Santa Catarina. Cienc Florest. 2012;22(1):193-206. http:// dx.doi.org/10.5902/198050985091.

Sonda C, Trauczynski SC. Reforma agrária e meio ambiente: teoria e prática no estado do paraná. Curitiba: ITCG; 2010.

Souza RF, Machado SA, Galvão F, Figueiredo A Fo. Fitossociologia da vegetação arbórea do Parque Nacional do Iguaçu. Cienc Florest. 2017;27(3):853-69. http://dx.doi.org/10.5902/ 1980509828635.

Ter Braak CJF. Canonical correspondence analysis: a new eigenvector technique for multivariate direct analysis. Ecology. 1986;67(5):1167-79. http://dx.doi.org/10.2307/ 1938672 .

Ter Braak CJF. The analysis of vegetation environment relationships by canonical correspondence analysis. Vegetatio. 1987;69(3):69-77. http://dx.doi.org/10.1007/ BF00038688. 